\title{
DIFFERENT WORLDS, DIFFERENT LANGUAGES: BRIDGING THE LAW-ECONOMICS DIVIDE IN COMPETITION LAW
}

\author{
by Lynette Osiemo*
}

\section{Introduction}

'The challenge for South African lawyers is to understand the relation between law and economics, to grasp the economic consequences of decisions taken in terms of the Act'. 1 This, Davis $\mathrm{J}$ says, 'become[s] important if South African competition law is to develop into a coherent body'. 2 The interaction between law and economics is fundamental to the nature of competition law and a deep understanding of the two disciplines is a prerequisite for decisions that would meet the objectives of competition law.

Competition law concerns the regulation of markets; competition policy seeks to 'remove or reduce the distorting effects of excessive economic concentration and corporate conglomeration, collusive practices, and the abuse of economic power by firms in a dominant position'. 3 This in itself calls for an economic analysis of market situations to assess the fairness of trade, and the evaluation of economic concepts such as dominance, market power, and market share, that define the relationship between players in the market.

\section{The law-economics dichotomy}

The law provides a framework for the communication of these concepts and a guide for their application. Nevertheless, law and economics are divergent in their outlook. While the law is generally a theoretical subject that seeks to regulate relations between people,

LLD student at the Centre for Human Rights, University of Pretoria.

M Brassey et al Competition Law (2002).

As above.

Department of Trade and Industry "The evolution of policy in SA proposed guidelines for competition policy: A framework for competition, competitiveness and development' http://www.compcom.co.za/aboutus/correctevolution/ 2CorrectThe\%20Evolution\%20of\%20Policy\%20in\%20SA.doc (accessed 9 April 2007). 
parties or groups, ${ }^{4}$ and applies an equitable logic in its analysis, economics is a numerical science that relies much on empirical data to substantiate theories proposed.

[T] he underlying division between law and economics is methodological and cultural. The two fields use different rhetoric, different styles of discourse, different epistemologies, and different literary forms in developing and articulating their respective accounts of the world. ${ }^{5}$

An economist is valued for his analytical skills, collecting relevant data and using it to define a hypothesis to support a given line of argument. Lawyers, on the other hand, are valued for their 'verbal quickness and agility, crisp thinking, penetrating insights and mastery of legal doctrines'. ${ }^{6}$ Theoretical arguments are more prized in law, and applied to solve problems, than data analysis. While economists are concerned with the efficient allocation of resources, the lawyers' main concern is the equitable allocation of resources. ${ }^{7}$

Economics looks to efficiency where the law looks to justice. 'If efficiency is the fundamental problem of economists, justice is the guiding beacon of law professors. ${ }^{8}$ While lawyers conceptualise a "reasonable" man as the background to their analysis and decisions, economists look for the 'rational' man. ${ }^{10}$ The reasonable man has societal objectives in mind; he behaves in a reasonable and prudent manner, with the welfare of others at heart, while the rational man is concerned with maximisation of his self interest for his private benefit. ${ }^{11}$ The relationship between the law and economics is not always straightforward:

From the beginning of the nineteenth century, the American elite was forced to choose between a legalist intellectual structure that stood as an important barrier to the redistribution of wealth and a consequentialist, efficiency-oriented, instrumental conception of the

GJ Stigler 'Law or Economics' (1992) 35 Journal of Law and Economics 455. The writer says that '[law], like other social institutions, came to be viewed by economists as an instrument for the organization of social life'.

$5 \quad$ AW Katz 'Positivism and the Separation of Law and Economics' (1996) 94 Michigan Law Review 2229.

6 WM Landes 'The Empirical Side of Law and Economics' (2003) 70 University of Chicago Law Review 180.

7 WZ Hirsch Law and economics: an introductory analysis (1979).

$8 \quad$ Stigler ( $\mathrm{n} 4$ above). Lawyers apply this reasoning to justify the categorization of conduct as per se illegal.

9 Hirsch (n 7 above) xii. 'Reasonable man' is a phrase especially applied in cases of negligence or contract law; denoting the legal standard the courts would apply in resolving a dispute before them.

10 Washington University 'The economic geography glossary' http:// faculty.washington.edu/krumme/gloss/e.html (accessed 1 July 2009). It defines the 'economic man' as a '[h]ighly abstract model of human economic behavior based on simplifying but extreme assumptions of perfect information and perfect ability to use such information in a rational way (i.e. to achieve optimal ends) [the attributes of this non-human 'person' describe the ideal actor in classical micro-economic and location theories 'who' processes information into globally optimal (locational) outcomes or (spatial) equilibrium patterns]'. As above. 
law which undermined the structure in the interest of economic development. $^{12}$

One of the major economists who drew a nexus between the two areas has a theory attributed to him which says 'forget about the law: look at costs and benefits to see how economic life is conducted'. ${ }^{13}$

With such a comparison between the two disciplines, how reasonable can an expectation of their complementarity be? This paper seeks to highlight the general understanding of economics by the lawyers and specifically in terms of the short history of South Africa's Competition Act, ${ }^{14}$ with a view of establishing whether there is a better relationship between the two fields or a greater appreciation by lawyers of the role of economics in the law. This paper will analyse arguments in the competition cases decided under the new competition law in order to assess how far the lawyers have come in the understanding of economics. The areas in which South African competition law has succeeded in appreciating and aiding the law-economics interplay will be highlighted, as well as those where it has not and where there is room for improvement. In carrying out this analysis, the objective of this paper is to answer the question of whether the gap between law and economics is likely to close, and to consider whether lawyers have come as far as they can reasonably hope to.

\section{Application of economics in competition law}

In South Africa, economics played some role in the formulation of the Competition Act, which provides an unambiguous definition of some economic terms, a definite improvement on the provisions of competition policy in other jurisdictions. ${ }^{15}$ Clear definitions are indispensable to the effective functioning of markets. ${ }^{16}$ In a peer review of the competition policy and practice in South Africa by the Organisation for Economic Co-operation and Development (OECD) in $2003^{17}$ it was noted that economics played a major role in the

12 MJ Horwitz 'The Legacy of 1776 in Legal and Economic Thought' (1976) Journal of Law and Economics 624.

13 Stigler ( 4 above) 457. This is referred to as the Coase Theorem after the author of The Problem of Social Cost, R H Coase, considered a pioneer in the field of law and economics.

14 Act 89 of 1998.

15 Sec 7 of the Competition Act, for example, gives the definition of 'dominant firms' with numerical precision. This provides certainty in the determination of dominance as opposed to when it is an abstract notion.

16 Competition Tribunal 'Annual Report 2000/2001' http://www.comptrib.co.za/ Publications/Annual\%20Report/Annual\%20report\%202000-1.pdf (accessed 2 June 2007).

17 Organisation for Economic Co-operation and Development 'Competition Law and Policy in South Africa http://www.icn-capetown.org.za/Publications/Reports/ South\%20Africa\%20Peer\%20Review.PDF (accessed 2 June 2007). 
Competition Tribunal's analysis of cases before it. 'The range of issues the Tribunal and the Commission have addressed is impressive, as is the economic sophistication of their approach.18 The Competition Tribunal, in many of the cases that came before it, applied considerable effort to analyse or call for relevant economic data to substantiate proposed claims and accept or dismiss them. The structure of the competition authorities also alludes to an attempt to implement an 'economics-based policy' that recognises the need for specialist economic intervention in a system hitherto 'preoccupied with legalism'. 19

\section{Interpretation of vague terminology in case law}

There are many areas that reflect an apparent failure of the said attempt as the vague notions provided leave room for a clash of meanings. Provision for 'monopolies' is one such example. The term 'monopoly' is not defined in the Competition Act. Where economics refers to 'pure competition' and uses 'monopoly' as a tool of analysis, the law talks of 'free competition' and uses 'monopoly' as a standard of evaluation. ${ }^{20}$ In legal terms, 'monopoly' is the restriction of competition while in economic terms it is the control of markets. ${ }^{21}$ In evaluating the impracticality of public policy resulting from inadequate legislation that does not appropriately articulate these divergent views, Edward Mason proposed a solution that requires the re-definition of the 'monopoly' problem and the provision of tests by which anti-competitive practices can be objectively evaluated. ${ }^{22}$ This would mean getting the economists and lawyers together so that each can play their role-definition of concepts and substantiating it with data by the economist, and the lawyer, having understood this, translates it into a workable framework for application.

The use of terms with ambiguous meanings in the Competition Act makes it easy to see the different minds of the forces behind the law. When the Competition Act prohibits 'excessive pricing' and says that 'excessive price' is the 'price for a good or service which bears no reasonable relation to the economic value of that good or service', 23 it makes inevitable the economic assessment of the conduct alleged to amount to excessive pricing in order to reach that conclusion, or otherwise.

As above.

As above.

ES Mason 'Monopoly in Law and Economics' (1937) 47 Yale Law Journal 36.

As above.

Mason (n 20 above) 46.

Sec 1 (ix) of the Competition Act. 
In the Mittal Stee ${ }^{24}$ case, decided in March 2007, the Competition Tribunal categorically spelt out its role in the economics of market play by saying that it cannot interfere in price determination, a practice that should best be left to the interplay of independent actors engaging with each other in the market place' and that it would 'defend the promise of competitive structures to deliver quality goods and services at competitive prices'. ${ }^{25}$ It is interesting to note that the reason given for the reluctance of 'competition practitioners' to engage in the determination of the right or wrong price is partly the 'massive technical difficulties entailed in determining the right or wrong price', ${ }^{26}$ and one cannot help wondering how effective competition law can be without engaging in this difficult exercise as a matter of course because otherwise, how is it ever going to arrive at a determination of the price?

The role of the competition authorities was restricted to:

[p]romote and defend competitive market structures and to guard against conduct on the part of market participants which seeks to undermine the promise of those competitive structures to deliver quality goods and services at competitive prices. ${ }^{27}$

This reasoning of the court bears out the classical argument that economics is concerned with efficiency (and would bring out all the economic data needed to prove the economic value of the alleged excessive price), and the law is concerned with the concept of equity and how this is brought about by the structure of the market.

South Africa's Competition Act, like competition laws in other countries, uses terms such as 'efficiencies',' predatory behaviour', and 'excessive pricing', which are hard to give practical meaning to. In the case of the merger application by Trident Steel and Dorbyl, ${ }^{28}$ in considering the provision that a merger would be allowed if the efficiency gains (section $12 \mathrm{~A}(1)(\mathrm{a})$ ) outweigh the anti competitive effects of the merger, the Competition Tribunal noted that the 'complexities of case by case balancing of gains against losses becomes too unmanageable to be of any practical value'.29 How else, would the Tribunal hope to define the term and apply it to give the effect intended by the provision? For economists however, efficiency is a 'descriptive concept' and 'they have a well defined algorithm for

24 Harmony Gold Mining Company Ltd; Durban Roodepoort Deep Ltd and Mittal Steel South Africa Ltd; Macsteel International BV Competition Tribunal 13/CR/ Feb04.

25 As above.

26 As above.

27 Harmony Gold (n 24 above) para 74.

28 Trident Steel (Pty) Ltd and Dorbyl Ltd Competition Tribunal 89/LM/Oct00.

29 Fisher \& Lande 'Efficiency Considerations in Merger Enforcement' (1983) 71 California Law Review 1625, as cited in Trident Steel (n 28 above) para 43. 
checking its presence that is elaborate enough to be interesting as a basis for professional discussion'.30

The difficulty of a practical application of the term becomes compounded by the fact that it is not an absolute term, '[w] wat is efficient depends on the empirical configuration of individual tastes and preferences and changes as those preferences change'. ${ }^{31}$ Moreover, a comparative analysis of other jurisdictions showed that there is uncertainty and ambiguity as to the extent of its application. As quoted in the judgment, there is doubt whether the theory of excessive pricing had worked in Canada, and that American writers differed on the extent of its application and that it had not been recognised in any case in Europe to date. ${ }^{32}$ Such a provision, while being entrenched in the law, which should provide a framework for certainty in its application, on the contrary gives room for endless argument by economists on the issue, leading to more questions than solutions.

\section{Economic analysis through the Harvard- Chicago school debate}

In the field of antitrust law, generally, a wide debate subsists that reflects the law-economics divergence of thought. In the history of antitrust law, there have always been two opposing interpretations of the role of competition law: one with a bias to legal reasoning and the other to the economic evaluation of conduct. The Harvard School economists argue that an industry's structure determines how effective firms in that market will be, leading to a presumption of illegality based on the conduct of firms with market power, totally disregarding any efficiencies that may arise from the transactions of the firm. ${ }^{33}$ The Chicago School economists, on the other hand, 'believed that markets were likely to correct against any competitive imbalances on their own, without intervention by antitrust regulators'. ${ }^{34}$ This is another clash of ideologies which bears upon the relationship between law and economics: one school's total belief in regulation, the other's in the economics of the market place to the total exclusion of the law.

The adoption of the Harvard School thought brought certainty in decision making because of the per se illegality of any action of a firm that fit the description prohibited with no need for complicated

Katz (n 5 above) 2245.

As above.

Trident Steel (n 28 above) paras 44-46.

TA Piraino 'Recionciling the Harvard and Chicago schools: A new antitrust approach for the 21st century' 82 Indiana Law Journal.

Piraino (n 33 above) 350. 
analysis of data. Such an evaluation of actions makes it clear to firms what kind of conduct to avoid. The Chicago School viewed this application as too harsh and preferred rather to delve into the complex analysis and interpretation of data to assess the exact impact of a given conduct before reaching a conclusion on their legality or otherwise. Whereas this approach is more beneficial to the competition equation by proscribing the harmful effects of a given conduct as opposed to the conduct itself, it 'mandates an empirical analysis of the economic efforts of competitive conduct ... making the outcome of cases more difficult to predict'. ${ }^{35}$ Consequently, lawyers cannot advise their clients with certainty; they cannot tell them how to conduct their business to be on the right side of competition regulation which is definitely a loss to the practitioner who seeks to provide a solution to every legal problem his client presents him with. The defect of this situation in law is especially appreciated when the weight accorded to court decisions is considered.

Precedent setting is a valuable tool in the development of the law, and would be even more so in the competition law jurisprudence which has only just began, being eight years since the enactment of the Competition Act which currently governs the competition law in South Africa. [W]ithin the legal culture, precedent and pattern are blend concepts. The community attaches normative weight to consistency and to the related values of fair notice; impartiality and treating like cases alike'. ${ }^{36}$ A disadvantage applying the Chicago School is that it erodes the role of precedent setting in the development of the law. It is only with the development of precedent that a 'coherent body' 37 of competition law can be developed. The rationale for the application of precedents is manifold: it creates certainty in decision making; it ensures a wholesome development of the law as opposed to arbitrariness created by the inconsistent deciding of similar cases by requiring divergence from set precedents to be justified, thereby leading to a comprehensive and systematic evolution of the jurisprudence of any given area of the law. ${ }^{38}$ In the absence of precedents, the courts will have to rely on statutes only for the decision of cases. However, this is not sufficient because in many instances, the statutes provide '[g]eneral propositions [which] do not decide concrete cases'. 39 There is need to further distinguish the particular facts of the cases and apply the provisions of the law in a given manner specific to the set of facts adduced in order to give

Piraino (n 33 above) 409.

Katz (n 5 above).

Brassey (n 1 above).

38 GB Shollei \& G Sator 'Precedents: Theoretical and practical foundations' Presentation at International Conference on African Legal Resources: Challenges and Opportunities of Legislative Informatics 21 March 2007 Abuja Nigeria http:// nigeria2007.akomantoso.org/Precedents_presentation.pdf (accessed 1 September 2009).

39

Lochner v People of the State of New York 198 US 45 (1905) 198 US 45. 
meaning to statute law, especially where such provisions lack certainty in meaning.

\section{The challenge of the lawyer in competition cases}

The case of Nationwide and $S A A^{40}$ reflects the simplistic thinking of the lawyers in economic issues. Nationwide brought a claim against SAA on three grounds, and failed on all of them. The arguments presented by the complainant were held to be too simplistic, which point to the economist's 'methodological commitment to positivism, 41 and the lawyer's almost absolute lack of it, or, at best, very basic understanding of its underpinnings.

The first ground of the complainant was predatory pricing under section 8 (d)(iv), which requires careful classification of costs to determine the fixed and variable costs, and further, a delicate evaluation of the outcome to reach a conclusion of predation or otherwise. The applicants' claim was founded on the passivity of the respondents despite the rising costs due to the unfavourable RandDollar exchange rate and the $56 \%$ increase in jet fuel prices. Based on their own calculations, Nationwide pegged the rational price increase at $20 \%$ and sought an order from the court for the respondents to effect this. Nationwide produced 'scant evidence' to support their allegation of below average variable cost pricing. In rejecting the simplicity of this argument, the Competition Tribunal noted that, in the competition law sense, failure to pass input price increases to consumers is not by itself anti-competitive because firms could accommodate this by being more competitive. The Completion Tribunal held that the $20 \%$ increase proposed by Nationwide was 'simple arithmetic elegance', which was not inevitable from an economic point of view.

The court noted that extreme caution needed to be taken in predation cases because the difference between predation and competition is thin and a wrong decision would lead to the elimination of competition and pro-competitive incentives of firms would be discouraged. This extreme caution can be translated to mean that supportable or indubitable economic data, which the judge is expected to bear in mind as he weighs all the evidence and arguments placed before him in order to avoid judicial error, is expected, keeping in mind that the aim of antitrust regulation is not to eliminate valid and rational decisions by firms in the exercise of their legitimate

41 Katz (n 5 above). 
commercial sense. ${ }^{42}$ In assessing such cases before them, the competition authorities are undoubtedly faced with a task that a lawyer with little or no economic understanding would not be able to manage competently.

In the United States, the Matshusita ${ }^{43}$ case heralded the predominant role economic theory would play in antitrust cases. Though decided in 1986, long after the interplay of law and economics was acknowledged and appreciated 'one of the legacies of Matsushita was an increased role for economics in antitrust litigation in general'. ${ }^{44}$ The petitioners in the case were Japanese-controlled American corporations that manufactured or sold consumer electronic products. The respondents were American companies that sold television sets. The petitioners claimed that over a 20-year period the respondents had conspired to sell television sets at artificially high prices in Japan while at the same time selling the television sets at low prices in the American market in a bid to drive American firms out of the American market for the consumer electronic goods. It was held that 'if the factual context renders the claim implausible, [that is, if the claim is one that simply makes no economic sense] respondents must come forward with more persuasive evidence to support their claim than would be necessary'. ${ }^{45}$ Following this reasoning, the petitioners' case failed 'for failure to conform to the rigors of economic theory'. ${ }^{46}$ The court went further to say that the success of predatory pricing schemes is inherently uncertain and that, because of the logic of predation, the monopoly prices would have to be maintained for a long enough time for the predator to recoup his losses and make some gain; predatory pricing schemes were 'rarely tried, and even more rarely successful'. 47 It was further noted that 'predatory pricing conspiracies are by nature speculative. They require the conspirators to sustain substantial losses in order to recover uncertain gains. ${ }^{48}$ Applying such a theory, the amount of evidence and economic analysis of the evidence required for a claim for predation to succeed is high. The court dismissed the claim, saying that 'mistaken inferences in

As above. The court went on to evaluate the United States and European Union tests applied to evaluate the prices charged, noting that some additional evidence was needed if the thin line was to be maintained; more than mere below-cost pricing must be shown, such as likely recoupment, as in the US, and plans to eliminate a competitor, as in the EU.

43 Matsushita Electrical Industrial Company $v$ Zenith Radio 475 US 574 (1986).

44 MA Salinger 'The Legacy of Matsushita: has this thing called economics gotten way out of hand' Paper Delivered at Loyola University School of Law, Institute for Consumer Antitrust Studies 29 September 2006. Salinger is the Director of the Bureau of Economics Federal Trade.

45 Matsushita (n 43 above) 587.

46 Salinger (n 44 above).

47 Matsushita (n 43 above) 589.

48 Matsushita (n 43 above) 588. 
cases such as this one are especially costly, because they chill the very conduct antitrust laws are designed to protect'. 49

The same extreme caution was expressed in the case of Nationwide and SAA where the court said that 'it [cases of predatory pricing] must be adjudicated with extreme caution because of the likelihood of judicial error is considerable and the costs of error are impressive. ${ }^{50}$ If predation is such a theoretical concept as the court held, and if the probability of making judicial mistakes in the unlikely event that such cases were brought to court was high, one wonders what the intention of the law is in proscribing the conduct. In such cases, economists are given a clear chance to display their expertise and construct mathematical concepts only they can understand and then persuade the court with expert arguments that reflect their 'individual preferences.' 51

Other arguments presented in the case were:

\subsection{Abuse of dominance by inducing supplier not to deal with a competitor under s 8 (d)(i)}

Nationwide claimed that SAA had agreements with travel agents that channelled business to SAA to the exclusion of Nationwide. The claim failed because Nationwide did not adduce data to define the relevant market. It was expected to have produced data to show the proportion of airline tickets purchased directly from airlines and the shares purchased from travel agents and show that the purchases through agents could be substituted by purchase by any other means. It should have shown how many travel agents were parties to the alleged agreement and what proportion of agency tickets they represented. The argument of Nationwide, like all the others in the case, supports the view that empirical research is esteemed much less than theory in legal circles. ${ }^{52}$ 'It would only be a modest exaggeration to say that most law professors regard empirical work as a form of drudgery not worthy of first class minds'. 53

\subsection{Engaging in an exclusionary act under s 8(c)}

It was claimed that SAA engaged in an exclusionary act in terms of the recruitment of its staff. Insufficient evidence was adduced to define the relevant market; there were many unanswered questions such as whether the market for Boeing pilots was the same as that of 'other'

Matsushita (n 43 above) 594.

Nationwide Airlines Ltd (n 40 above) 11.

n 58 below.

Landes (n 6 above).

As above. 
pilots; whether Boeing pilots are substitutable by 'airbus captains' or 'executive jet plane captains'. These are hair-splitting arguments for the lawyer, but undoubtedly indispensable in the determination of the issue. Nationwide went on to prove its case against SAA by arguing that it could have 'hired the many unemployed pilots' instead of poaching its pilots. Again, no evidence of unemployment was adduced; where the Competition Tribunal would have required empirical data to prove their claim, Nationwide adduced only theoretic evidence - another show of the disparity between law and economics that leads to the inevitable failure of mere rhetoric to support a case in competition law.

\section{The role of the judiciary ${ }^{54}$ in competition law jurisprudence}

A major criticism of the interplay between law and economics is that lawyers and judges do not speak the economic language. ${ }^{55}$ The judiciary is composed of judges who usually are only required to have a legal training. Being from such different backgrounds, the 'economist and the lawyer live in different worlds and speak different languages'. ${ }^{56}$ Lawyers who bring and defend cases before it are also mostly only trained in the law. There will inevitably be difficulty in analysing, discussing and deciding on matters that have an economic bearing.

In what may be viewed as an attempt to take care of this problem, the South African competition legislation creates specialised regulatory institutions to enforce competition laws. The Competition Act makes provision for the establishment of the Competition Commission $^{57}$ ('the Commission'), the Competition Tribunal' ${ }^{58}$ ('the Tribunal') and the Competition Appeal Court' ${ }^{59}$ ('the CAC'). The Commissioner of the Commission and his deputy, and each member of

54 The term judiciary is used here to refer to the judges who hear competition cases, including those in the Competition Tribunal and Competition Appeal Court and is not restricted to the bench as commonly defined.

55 RA Posner Economic Analysis of the Law (1992) 25.

56 Stigler (n 4 above) 463.

57 Sec 19 of the Competition Act. The Commission is 'empowered to investigate, control and evaluate restrictive business practices, abuse of dominant positions and mergers in order to achieve equity and efficiency in the South African economy'.

58 Sec 26 of the Competition Act. The Tribunal is empowered to adjudicate on any matter concerning prohibited practices and hear appeals and reviews from the Commission.

59 S 36 of the Competition Act. The CAC is established under sec 166(e) of the Constitution of South Africa. It reviews the decisions of the Tribunal and hears appeals from the Tribunal. 
the Tribunal are required under the Competition Act to possess economics and law qualifications, ${ }^{60}$ undoubtedly in view of the inseparable nature of the two disciplines in matters of competition law. There is however no similar statutory requirement for the members of the Competition Appeal Court, who are only required to be a judge of the High Court. A judge of the High Court is required to have legal qualifications under the law. The President is advised by the Judicial Service Commission in the appointment of these judges and consequently those judges with a 'specialist interest in competition law'61 sit in the CAC. There is no legal requirement that persons with sound economic knowledge be appointed. If economic knowledge is considered necessary for the members of the Commission and Tribunal, is it not because there is a realistic need for such know knowledge? If the answer to this question is in the affirmative, why is the same not required with as much certainty of the CAC, which handles matters arising from the Commission and the Tribunal?

In a review of the functioning of the CAC made in 2003 by the Tribunal, the lack of economic expertise of the court was noted, and it was said that:

One would hope that the CAC will develop more perspective and expertise about substantive issues than the High Court itself has shown in the handful of review matters that have come to it. But so far, the CAC's formalistic decisions look more like those of a High Court of general jurisdiction than those of a court with specialized substantive expertise. In the only CAC decision on the merits of a merger, the reasoning is doctrinaire and derivative, revealing that the judges are more comfortable referring to treatises and legal presumptions about economic effects than they are deferring to the Tribunal's assessment of economic evidence. ${ }^{62}$

How could any better analysis of substantial issues be expected when the composition of the court is such that it inherently lacks required expertise?

In the $A_{n a c^{63}}$ case the matter was taken on appeal before the Supreme Court of Appeal. This set a precedent hitherto unforeseen. In a speech given by the Chairperson of the Competition Tribunal at the International Society of Consumer and Competition Officials (ISCCO) Conference in June 2000, barely two years after the coming into effect of the Competition Act, and less than a year after the commencement of its practical enforcement, the Judge noted that:

60 Sec 22, 23 and 28(2) of the Competition Act.

61 D Lewis 'Competition regulation: The South African experience' International Society of Consumer and Competition Officials (ISCCO) Taipei 21 June 2000.

62 Competition Commission 'Competition law and policy in South Africa' OECD Global Forum on Competition Peer Review Paris 11 February 2003.

63 American Natural Soda Ash Corporation $V$ The Competition Commission, Botswana Ash (Pty) Ltd and Others SCA 554/03. 
The investigation and adjudication of all matters under the Competition Act is the province of specialist agencies. No decisions of the Commission, the Tribunal or the Appeal Court are subject to ministerial veto. Not even the Supreme Court of Appeal, the highest court in the land, has jurisdiction over competition matters. ${ }^{64}$

This was a logical conclusion in view of the nature of the matters that go before the independent bodies, which are best suited and adequately staffed to hear and decide those matters. The South African position was deemed more favourable for several reasons. Firstly, the Tribunal is 'an expert decision making body composed of representatives of the disciplines - notably law and economics but also potentially chartered accountants - that contribute to the makeup of this unusual branch of law and economics' ${ }^{65}$ In addition to this, the Tribunal members meet regularly to discuss and keep abreast with specific aspects of competition economics and law. ${ }^{66}$ Secondly, the CAC judges hear a large number of competition cases, making them specialists in this area, unlike other jurisdictions where 'generalist' judges adjudicate competition matters. Whereas their competence cannot be questioned, it is undoubtedly more advantageous to have these same judges with experience in the judiciary with its 'traditions and unique contributions' apply this experience to the "sufficient "critical mass" in the practice of competition law [thereby being better] able to develop a working familiarity with this unusual, dynamic field of the law'. ${ }^{67}$

Nevertheless, six years later, the highest court in the land ruled that it had jurisdiction to hear a competition law matter on appeal from the CAC in view of the Competition Act's 'own injunction [which provided that] it must be interpreted consistently with the Constitution'. ${ }^{68}$ Such an interpretation, the court held, would mean that the 'finality conferred on the CAC by the Competition Act (sec $62(3)(c))$ is subordinate to the appeal powers that the Constitution conferred on [the Supreme Court of Appeal]. ${ }^{69}$ Leave was granted on the basis that the requirement of special circumstances was satisfied; the court nevertheless emphasised the fact that the matter had already had a full appeal before the CAC, which would usually weigh heavily against the grant of leave. A precedent was set in this case the specialised tribunal does not have the final say in competition matters. This precedent detracts from the uniqueness of the South African competition regulation authorities, and leaves the question

64 Lewis (n 61 above).

65 Competition Tribunal 'Challenges/Obstacles Faced By Competition Authorities In Achieving Greater Economic Development Through The Promotion Of Competition' http://www.icn-capetown.org.za/Publications/Speeches/oecd_20 oct.pdf (accessed 29 May 2007).

66 Competition Tribunal (n 16 above).

67 As above.

68 Competition Tribunal (n 60 above).

69 As above. 
open as to how effective adjudication can take place in a nonspecialised tribunal in view of the complexity of the issues brought before it.

It may be argued that this problem may be sorted out easily by judges using the expertise of economists to evaluate evidence in competition cases, much to the same end as the specialised tribunals. While there is some truth to this proposition, it is not without its shortfalls.

In some instances, economists are viewed by lawyers as 'input to their product - the persuasion of judges'. ${ }^{70}$ Because the lawyer's concern is to win the case, the 'economist's affidavit usually turns out to be just a second lawyer's brief in different language'. ${ }^{71}$ In a situation where numerous volumes of economic data is put before the court, including complex calculations and theories based on numerous assumptions, how is a judge (with little understanding of the functioning of economics) expected to make a learned conclusion?

In proposing a solution to this problem, an inquisitorial advocacy system is preferred ${ }^{72}$ to the adversarial one where the parties are led by structure in presenting and getting information. In an inquisitorial system there is more interaction and questioning and the judge can thereby get all the information and explanation he needs to reach a decision. On this point again, the South African system is notably a step ahead; 'the Competition Act enjoins the Tribunal to conduct itself informally'. ${ }^{73}$ It specifically frees the Tribunal from some of the more constraining elements of high court rules with regard to the preparation of pleadings and the admissibility of evidence. In what is, without significant exception, a classically adversarial legal system, the Tribunal is accorded (undefined) 'inquisitorial' powers."74 But this, again, is not without its criticism. An economist, being well versed in his area of expertise, and being aware of the judge's limitations in understanding his propositions, may use it to his advantage. The impropriety of using economists in this role was acknowledged by a judge who stated that '[n]o judge ought to have at his elbow a man who is not subject to examination and crossexamination by counsel and who has intellectual mastery sufficient to control a judge'. ${ }^{75}$ Their argument would be that, even if their theories were not quite accurate, the judge would not know. By their

KW Dam 'Economics as a guide to antitrust regulation: comment' (1976) 19 Journal of Law and Economics 385.

As above.

Dam (n 70 above) 386.

Rule 55 of the Rules for the Conduct of Proceedings in the Competition Tribunal requires the presiding member of the Tribunal to give directions in the event that a person is uncertain on how to proceed, and gives it the power to condone any technical irregularities that may arise in the course of the proceedings.

Competition Commission (n 62 above).

Dam (n 70 above) 386. 
very arguments these 'experts' can lead the judge to erroneous conclusions.

Economists usually apply methodological mathematical models in their evidence to simplify the theoretic abstractions they adduce in their arguments. ${ }^{76}$ 'The particular examples and the rhetorical aspects of the narrative, being chosen with the goal of persuasion, necessarily will reflect the individual preferences and normative commitments of both the modeller and the audience'. ${ }^{77}$ Whereas economics provides the framework for policy application, the law has not succeeded in translating this framework into clear concepts that can be applied without ambiguity. Consequently, economic notions remain unclear and any attempt at justifying them has produced a confused body of translations.

In April 2006, a report ${ }^{78}$ based on a survey on members of the International Competition Network, which included contributions by the South African Competition Commission and Competition Tribunal, was released. The survey was carried out by the International Competition Network Competition Policy Implementation on the relationship between Competition Authorities and the Judiciary. ${ }^{79}$ The 'objective was to examine competition authorities' perceptions about instances where courts and competition authorities come to different conclusions' 80 and it concluded in part that 'the independent and effective review of competition agencies' decisions by courts is a necessary, critical, and an important aspect of many well-functioning competition regimes. A judiciary familiar with competition law including its economic aspects is an important element of a country's competition policy system'. ${ }^{81}$ Among the reasons given by the respondents for the divergent views of the competition authorities and the judiciary is the fact that judges are

AW Katz 'Positivism and the separation of law and economics' (1996) 94 Michigan Law Review 2242.

77 As above.

78 International Competition Network 'Competition and the Judiciary' http:// www. internationalcompetitionnetwork.org/media/library/ conference_5th_capetown_2006/CompetitionandtheJudiciary.pdf (accessed 9 April 2007)

It is noted that the report is a generalised one, giving a summary of the respondents' responses, and in view of this the interrelation between competition authorities and the judiciary, may vary greatly depending on the structure of the competition law regime in each country. In South Africa, an independent competition authority exists; nevertheless, the recent decision of the Supreme Court of Appeal in the Ansac case sets precedence for a more interactive relationship between the competition authorities and the judiciary in the future. Consequently, the role of the judiciary may be interpreted as in the report "to "shape" competition policy can mean building a policy and developing it further by determining its purposes and the interests it should protect in the absence of comprehensive and detailed competition laws and regulations (as is done by the judiciary in a common law system)'.

80 Internation Competition Network (n 78 above).

81 Internation Competition Network (n 78 above) 4. 
not sufficiently familiar with the economic concepts needed to assess competition cases (this was viewed by most as the reason for the difference in views) ${ }^{82}$ and also that there are divergences in the way competition authority and the judiciary interpret the competition rules. These findings support the typical lawyer-economist divergence of thought and the approach discussed above and would need to be addressed for a harmonious relationship to result and for a coherent development of competition law. One of the recommendations made in the report is the "urgency to bring judges closer to the technical analysis made by competition authorities, especially in developing countries'.83

Speaking from the point of view of the Tribunal as an adjudicative body at a Competition Law Conference, ${ }^{84}$ Davis J proposed for the future consideration of the Commission the possibility of reducing the evidential burden in cases by 'developing more effective methodologies for gathering and placing before us evidence derived from consumer surveys and studies,85 as opposed to the unsophisticated and voluminous procedures currently applied. While appreciating the impact economics has had in the short history of the new competition regime in South Africa since the enactment of the Competition Act in 1998, the need for the essence of competition law not to be detracted from is nevertheless underscored and its (economics') application is subject to certain logical applications to ensure practicality. In considering this new approach one consideration must be kept in mind, that 'unless we can be certain of the capacity of [our] legal system to absorb new doctrine, our attempts to introduce it will only be more ludicrous in failure and more costly in execution' ${ }^{86}$

So where does the solution lie? Specialised courts present the best answer - having judges knowledgeable in economics and the law sitting in competition matters. Once this structure is guaranteed, the challenge then will be that of staffing it competently - a much easier problem to tackle.

\section{Conclusion}

However much the gap between law and economics has been lessened since the earliest interaction of the two disciplines, and with the

Internation Competition Network (n 78 above) 15

Internation Competition Network (n 78 above) 16.

The First Annual Competition Commission, Competition Tribunal and Mandela Institute Conference on Competition Law, Economics and Policy in South Africa 21 May 2007.

85 Davis J, opening speech at Competition Law Conference http://www.icncapetown.org.za/Publications/Speeches/lewis10.pdf (accessed 29 August 2008).

86 DC Bok 'Section 7 of the Clayton Act and the merging of law and economics' (1960) 74 Harvard Law Review 228. 
development of antitrust law, the fact remains that 'the two professions are trying to do different things, and they have different professional identities and aspirations and different ways of talking'. ${ }^{87}$ There is recognition that in balancing the legal-economic equation, certain areas are best left to economics and others to the law, while in some instances the courts give a view of being too mixed up in unclear waters that they opt to be left alone (when ambiguous decisions are given or cases decided on procedural technicalities rather than substantive issues).

The theory of perfect competition presents an inherent problem in the interplay that offers no easy solution because '[i]t has never been shown to exist and is a most improbable phenomenon'. ${ }^{88}$ Some of the assumptions made by economics are: the assumption of perfect competition and that all consumers can distinguish between different goods; the assumption of mobility, that resources flow easily from one market to another because barriers to entry do not exist; the assumption that there are no externalities because the parties to a transaction bear all costs and revenues associated with the production of that good or service; and the assumption of homogeneity, that products are not differentiated. Are these assumptions real? What is their bearing on reality? A person who has little or no knowledge of economics will strongly argue against its rationale. An economist, however, argues that it is necessary to make the assumptions 'for the obvious reason that the world, viewed economically, is too complicated to understand without abstraction. 89 The danger of this would be for the economist to assume a free choice of assumptions that has no ability to explain reality; or for an analyst to seek to make a simple model complex by bringing in too many assumptions and running the risk in the process of finding himself with too many degrees of freedom; creating a model so rich that no empirical evidence can refute it, and which can neither be supported by any observation. ${ }^{90}$

A basic economics understanding by any lawyer or any lawyer who deals with competition law matters is imperative if he hopes to put a check on the economist's capacity to reach any conclusion he wishes by alluding to complexities beyond the lawyers' understanding. To repeat the words of Brandeis $J$ 'a lawyer who has not studied economics ... is very apt to become a public enemy' 91 due to the inevitable interaction of the disciplines in many areas. To the extent that competition law requires the inevitable consideration of economics, lawyers must understand the subject.

Katz (n 5 above).

Hirsch (n 7 above) 239.

AM Polinsky An Introduction to Law and Economics (1989) 2.

Posner (n 55 above).

Hirsch (n 7 above) xi. 
A good starting point, as many have acknowledged, is the teaching of economics to law students. This has led to many law schools having economists in the law school. In giving an evaluation of the development of economics and the law, Posner and Landes are of the opinion that the largest contributions in the two areas have been legal teaching and scholarship 92 where they say that 'the effect can fairly be described as profound'. 93 This is because economic knowledge of lawyers is undoubtedly essential because [i]t is widely recognised that everything bearing on the solution of social problems bears on what we study and teach at the law schools'. ${ }^{94}$

Whereas law lecturers may be aware that 'they are not sociologists, philosophers, psychiatrists, political scientists, real scientists, or economists, they are also aware of the incompleteness of legal doctrine considered in isolation from the learning of those other fields'. ${ }^{95}$ In recognising the role played by other fields in the law, 'an understanding of the social structure in which law operates can no longer be taken for granted or regarded as irrelevant; law students and hence law teachers must acquire that understanding, and must somehow learn to take into account the contributions which other disciplines and sciences can make to the solution of social problem. 96 The university can thus play an important role in the teaching of economics to students as part of the curriculum, preparing them to participate usefully in the development of the field of law and economics, an area fundamentally important and inseparable in considering competition law. The lawyers who emerge from there will thus be in a more competent position to provide useful safeguarding against the application and interpretation of economic analysis in deciding competition cases.

WM Landes \& RA Posner 'The influence of economics on the law: a quantitative study' (1993) 36 Journal of Law and Economics 385. As above.

P Areeda, 'Always a Borrower: Law and Other Disciplines' (1988) 5 Duke Law Journal 1038.

As above.

As above. 